\section{FUTURE OF BIOLOGY IN WORLD AFFAIRS*}

\section{By $D_{R}$. FRANS VERDOORN}

$\mathrm{D}$ URING the last months of the War of 1914-18, a period which--from many points of view-may be compared with the present, the plant scientists and zoologists of the world were less in. volved in the war effort than they are to-day. Nevertheless, as such addresses and papers as Lyman's "Contributions of American Botanists for More Active Prosecution of War Work" (1918) and Stevens's "American Botanists and the War" (1918) show, some of the foremost plant scientists of the United States were prevailing upon their colleagues to engage in activities which might help the war effort. At the same time much consideration was given to the War from a biological point of view, as such publications as Nicolai's "Biology of War" (1919) and Pearl's "Biology and War" (1918) testify. Just before the end of the War many interesting papers on the role of botany and biology in the post:war world were published. These included "Botany as a National Asset" (Coulter, 1917) and "Botany after the War" (Davis, 1918), and were followed by an unusual number of inspired discussions by men like Lyman, Peirce and Gager. Though during those years a number of biologists did accomplish useful things in such fields as pioneering in dehydration, raising the agricultural output and discovering substitutes of vegetable origin, the foremost trend of thought, especially in the Allied countries, was concerned with biology in the post-war world, in human relations as well as in agriculture, etc. The Germans of that time were, comparatively, much more concerned with problems directly relating to the war effort than were their colleagues in the Allied countries. Diels wrote an entire volume on botanical substitutes; Haber and other chemists revolutionized the fertilizer situation.

In the discussions in Allied countries the educational and humanizing value of biology was stressed much more than it is to-day. Many believed that a better knowledge of, and better training in, biology might well revolutionize the citizen's attitude towards essential problems of life and human relationships. This hope has not materialized-and that, without doubt, is a reason for the sceptical and negative attitude of many of us to-day.

In one field, however, enthusiasm, understanding and leadership on the part of the biologists of the Allied countries was scarcely progressive. It strikes the historian as strange that in those Wilsonian years very little was said, in either British or American discussions, about international work and relations in science, the re-establishment of international relations, etc. There was a much more patriotic (though not a soundly patriotic) tone in the discussions then than there is to-day, when it looks as though groups of men of science (not necessarily natural scientists) in Great Britain and the United States are at least as much interested in post-war international relations as are the large political groups. It was in 1919 that Livingston turned down Lotsy's generous offer to combine the planned Botanical Abstracts with the

* From an address entitled "The Plant Scientist in the World's Turmoils", contributed by Dr. Frans Verdoorn (of Arnold Arboretum and editor of Chronica Botanica) to a symposium on "Biologists and Rehabilitation" held by the Botanical Society of America and the American Association for the Advancement of Science at Cleveland Ohio, on September 13.
Botanisches Centralblatt, at that time-in spite of its name-a purely international journal and the official organ of the now defunct International Association of Botanists. This rejection killed that Association and much that it stood for, and postponed for years a resumption of international relations work in botany, so enthusiastically started before the War of 1914-18 by men like Scott, Goebel, Farlow, von Wettstein, Trelease and many others.

When war broke out in 1939, international relations work in science had not yet fully recovered, nor by any means reached the status of 1914-this in spite of the many congresses, meetings and commissions in our field about which I have reported in great detail, in an effort to stimulate interest in them, in special sections of Chronica Botanica, volumes 1-3. Reading those reports of the years before the present War and comparing them with those during 1912-14 creates the conviction that an unsound impetus was given during the years just before this World War by motives only slightly differing from national propaganda.

In this War the biologist has played a much larger part than in any previous war. Botanists, agronomists, zoologists, entomologists, psychologists and bacteriologists have contributed in larger numbers and in more intensive ways than ever before to the war effort. Men of science form one of the few groups in society which know that the concepts and ideas by which politicians and the accepted organizers of human relations are guided are mostly wrong, based on misconceptions, old superstitions and false intuitions. Yet the man of science has left not only the administration, but also most of the study, of the administration of human life and world affairs in the hands of people who are not very appreciative of what a century of progress in the science of life has achieved. Therefore, I cannot help feeling that men of science are more truly responsible for the chaos of to-day than any other part of society.

The resources, strength and endurance of the United States, the British Empire and the U.S.S.R. and their allies are bringing this War to an end, an end which will place the man of science once again in a very favourable position, as he will remain free in the post-war world, not in all but in much more than half of the Allied territory. How will he use this freedom of thought and action?

I want to begin a discussion of the peace tasks of the man of science with a most dificult problem, which logically does not come first at all. Yet it is so important and most of us are so consistently dodging it that I feel I must bring it up before anything else.

When we speak of the re-establishment of international relations, I believe that most of us think primarily of Great Britain and other Allied countries. Most of us do not think clearly about the re-establishment of relations with the present enemy countries, especially with Germany. Yet there can be no doubt that it is essential that workers in science, the humanities, and the arts understand that they are the members of society best fitted to pioneer in the re-establishment of relations with the enemy and that it is necessary for them to prepare to do so at short notice. Intellectual life, as Raymond Fosdick has said, is the most fundamental unity of modern civilization, and that life cannot be broken in parts without disaster. This is the most obvious reason, clear to anyone, for a demand for a quick and thorough re-establishment of international relations 
in science and the humanities. But there is another reason with which not everyone may agree as quickly but which seems to me at least as important. Peace, progress and human well-being generally depend upon the integration of present enemy countries in some system of full international co-operation. Biologists know that our world needed millions of years to develop to its present status and that it will need some time to develop into a commonwealth of nations. Yet the trend of the development of mankind is in that direction, and the groups best fitted to do so have to go ahead and assume leadership. The necessity for this was expressed in more detail already early during this War by a manifesto of fifty-seven members of the Royal Society of London. It is the duty of the men of science to the world-and therefore also to their own countries-to re-establish relations with enemy colleagues both individually and through meetings, congresses and international commissions, in all fields (also where the activities of many Allied research workers are controlled by trusts) to the fullest possible degree and as soon as circumstances permit. We must do this whatever practical commands for dealing with Germany, German split States, etc., may be, in order that the German man of science will not 'go underground'. The world of science needs him, but the world at large needs him still more. The mistakes made after the War of 1914-18, when most international co-operation in science was started in France, more by politicians than by men of science, and restricted to Allied and neutral countries, must not be repeated, even though we know that some of our enemy colleagues will use purely scientific co-operation for other purposes.

To enter again into mutually useful relations with colleagues in enemy countries, it will be necessary to realize that some of them think as we do, but many of them do not. To deal with these men it is necessary to realize that the Totalitarian State, in which the younger ones especially believe and may continue to believe, is a form-evil, we may think-of world evolution. It has enabled men, men of science, social workers and others to do things in science, research, teaching, social applications, etc., which are not necessarily evil-as is often tacitly assumed only because they were made possible by a Fascist Government. Especially in the biological and agricultural sciences much that was excellent was done during the pre-war years in the Axis countries. Study, understanding and realization of these things is a necessary basis for a good programme of the reestablishment of relations, 're-education', etc. The politician, let us never forget, has to emphasize what divides ; the man of science may well emphasize what unifies. Workers in pure and applied biology are in a specially favourable position to pioneer in this field. The problem of intellectual relations with Germany demands more than goodwill; it asks for effort and study.

Speaking of agriculture in the post-war world, Dr. Auchter, of the U.S. Department of Agriculture, in a recent address emphasized (1) improved nutrition for human beings, (2) methods of breeding and the use of substances that regulate growth, (3) world exploration to obtain and maintain material for breeding purposes, (4) the changed fertilizer situation, (5) utilization of waste and by-products, and (6) problems of insect and disease control. To them I should like to add research in a field about which we heard more at the end of the War of 1914-18 than to-day. In spite of the lack of emphasis on international relations at that time, there were in the minds of our colleagues, a generation ago, a number of ideas, or rather a feeling, for the necessity of closer relations between science and government (not necessarily human politics). We might call this borderland biopolitics. I miss a plea for it to-day. Is it because we have despaired of ever establishing such relations ? $\mathrm{Or}$ is it a reaction against the close relations between biology and politics in the U.S.S.R. in which biology has occasionally been reduced to serfdom? If that is so, a word of warning must be expressed. To do so I just used the word biopolitics, which will recall a related field of research, geopolitics, developed by and first used in the Axis countries, but, once again, not evil on that account, as shown by the ways it is now being developed along purely scientific channels by American scholars. Biopolitics and geopolitics may well be the ways along which men of science will find it possible to reach those groups which they hitherto failed to influence.

It is not true that the two World Wars are simply conflicts between have and have-not nations; yet the conflicts between these two groups are more responsible for the twentieth century chaos than are any other conditions. The practical politician will deny this vehemently; the man of science knows better. H. G. Wells in 1940, in "The New World Order", considered it the second most important of the four major causes of war. The man of science, the only reliable authority on natural resources and the possibilities of their development, may well contribute a major share to the establishment of a durable peace. He also knows that a durable peace will have to be plastic-a consideration which the practical politician again considers absurd.

One of the resolutions of the United Nations Conference on Food and Agriculture states: "The natural sciences are a particularly fruitful field for international co-operation because they are themselves international ; basic physical and biological laws are the same anywhere and universally accepted". This is true, but it is also true that co-operation demands an attitude which is not typical of the average biologist. Considering the matter psychologically, most of the better workers in botany and zoology turned to this pursuit because early frustrating experiences resulted not in the normal, human response of aggression, but in a desire for isolation. It is perhaps a bit hard to demand now that these men become enthusiastic co-operators. We will, however, have to assume that at least some of them have learned that even in a Nature research it is true that 'united we stand, divided we fall'.

Sometimes I speak of plant scientists, sometimes of biologists, sometimes of botanists. This inconsistency is not due to carelessness, but to a tragic fact, to the greatest professional problem we have: there are no longer biologists or even animal scientists and plant scientists.

There was a discussion some months ago in the columns of Science about whether there still exists to-day such a subject as biology. Some of the writers stated that it was a fraud to speak of biology any longer, as we always mean something else. There is, of course, such a subject as pure biology when considered from a purely scientific or philosophical point of view, but there are no longer professional biologists. There are only specialists in the various branches of the pure and applied plant and animal sciences. What makes it bad is that these specialists do not keep together or think and plan together 
with reference to their professional interests as medical and chemical workers do. Though very large in number (22 per cent of the men of science included in "American Men of Science" (ed. 7) are "Biologists" sensu antiq.), our position both as a group and as individuals is extremely weak. As wage earners we are in many cases not able to give our families the comforts and education which we received in our youth or which the families of our friends in college receive; as men of science we have either to teach or to work in applied biology, with the result that many branches, especially of descriptive biology, have an anachronistic status; as a group we cannot exercise an influence commensurate with our knowledge.

Mutatis mutandis, this situation is the same all over the world. From this it appears that the situation is the result of internal factors, and that it cannot be changed easily, for example, by establishing professional biological societies, unions, etc., especially not so long as-another curse of biology-its great men of science continue to refuse to give professional guidance.

With every generation an increase in specialization seems to become necessary. This may be really essential, but the result is that many workers spend their enthusiasm and greatest mental output in their youth, and end with years of not-too-inspired routine research. Great as the literature and body of facts of any branch of biology may be, I do not agree that all this specialization is necessary. The organization of most of our institutions is such that it forces the so-called free worker into a steady and dull routine.

We all, but the administrators of research especially, should distinguish between deep and permanent specialization. But even if we feel that permanent and deep specialization is necessary, can we not educate our pupils with the feeling that they are in the first place biologists, whatever they do, and specialists in some branch of the pure or applied plant or animal sciences in the second place? No improvement of the status of biologists is possible if they do not recognize the very close interdependency between pure biology and applied biology on one hand, and between biology and world economy and government on the other hand. Also all biology, in contrast to physics, mathematics, etc., continues to have close ties with the humanities. We cannot fulfil our mission if these facts are disregarded; we cannot raise a satisfactory crop of young biologists if we and they are not governed by this knowledge.

Now let us consider the aims of international co-operation in science:

(1) The exchange of information (scientific, professional and practical) in such a way that it will be available to anyone who can profit by it.

(2) The attainment of objectives which individuals or men of science of a single institution or nation cannot accomplish. These may be either in pure or applied scientific research, or they may be co-operative scientific or practical publications.

(3) The forming of an esprit de corps which may, at least at some time and at some place, counteract the evils of human international polities and contribute towards the establishment of a commonwealth of nations.

How can we best accomplish these aims?

(1) By the oldest and most important form : the publication of original research, in which every man of science takes part, uninterrupted even by war, every time he has an article or a book published. I find an increasing assumption that scientific publications, not research or knowledge, are the most important thing to-day. We all know that the number of publications is increasing more rapidly than our real knowledge. In two fields with which I am familiar enough to express a judgment, bryology and history, about half the papers of the last forty years have brought only material that needs revision, checking or completion, and that does not really, or only very immaterially, add to our knowledge. Many workers in these fields die without ever having contributed anything to the real advancement of their chosen field. A single monograph, a single well-planned handbook, could have been prepared in the same time now wasted on many little papers. Unfortunately for many of us, the question no longer seems to be how to contribute best to the advancement of science (the fact that many of us can contribute better to our science as a whole by various forms of organizing work is also too often forgotten), but how to make the best impression.

(2) By abstracting journals, international as well as regional.

(3) By international congresses and meetings.

(4) By international societies or commissions, responsible for the organization of international cooperative research. In biology most research is individual, or at most institutional ; whereas in other fields of science, for example, astronomy and geodetics, research has developed markedly along lines of direct co-operation, national and international.

Though it is clear that most research in biology will remain quite individual (this should be recognized as the cause of the comparative lack of interest of many foremost biologists in international relations work), there are many scientific and especially applied scientific problems which could more easily and better be solved by some form of international co-operation. In taxonomy, for example, the terrible status of exotic cryptogamic taxonomy cries for some kind of concentrated attack ; in plant pathology, a study, on an international basis, of the methods of disease control is greatly desired; in horticulture, an international centralization and further experimentation on the results obtained by the use of hormones in'propagation has been asked for by the Permanent Committee of the International Horticultural Congresses.

(5) By international societies or commissions responsible for the organization of practical international activities. In botanical and zoological nomenclature the need for such co-operation was felt at so early a time that much has already been accomplished in this field. There are, however, many other things which could and should be done in the same way : the unification of botanical terminology, colour codification, etc. Such work as has been initiated by Prof. Record's International Association of Wood Anatomists could usefully be done in many other fields. A special war-time problem-and an immense one-is the reconstruction of herbaria and botanic gardens destroyed during the War; this is an international, not a national, task.

(6) By publications not reporting the results of scientific research (either in original form or in abstracts), but bringing together various kinds of information and intelligence. In some cases these may be only stimulating; in other cases, of direct use for the research worker. Publications of this type have played a great part in biology; and I have always been especially interested in them. We may distinguish : 
(a) Address-books, either the old-fashioned lists of research workers or the more modern combination of such lists with a census of current research.

(b) Indexes of various kinds; for example, the Index Herbariorum, started by Dr. Hitchcock and now actively continued by Dr. Lanjouw.

(c) Such journals as the early Botanische Zeitung, early Botanical Gazette, Dörfleria, the Chronica Botanica when it was published as an "International News-magazine". Such journals which bring together various kinds of information and intelligence, discussions, notes, news, etc., have in the past always been published by individuals who after some time could not continue to give them the necessary time and money. They should, of course, be the official professional organ of an international society.

(d) A very great need exists also for a new and complete guide to the literature of the plant sciences. This also will be possible only with international co-operation.

(e) Then there are many publications, semiscientific, semi-practical, like the "Index Kewensis" and "Index Londinensis" and my planned "Index Botanicorum", which were formerly compiled on an institutional or national basis, but which, in the future, will probably ask for an international effort.

None of these things in itself is very important, but together they make a complex mass of activities both inspiring and helpful, and well worth the effort, even if we realize that to do this work well some of those who will do it will have to give up projects in pure research dear to their hearts.

Just as a commonwealth of nations, the goal of almost all thinking men, is not yet in sight, it is clear that the time for some of the activities just enumerated is not yet here. The tendency of human development, in any field whatever, is, however, toward greater unity. Before there can be anything like a world-embracing commonwealth of nations, regional commonwealths may be more immediately feasible. Pan-Europe as planned by Briand and Coudenhove Kalergi is one of them ; a united Western Hemisphere as planned by Simon Bolivar and Henry Clay, and to some degree established by Sumner Welles, is another. One does not have to be very familiar with international politics and relations to realize that a united Western Hemisphere is one of the greatest conceivable guarantees of a durable peace. Unfortunately we have learned during the past years that differences in race, temperament and economic interests make a united Western Hemisphere-which, at no time, seemed too Utopian-not so easy to accomplish.

Here the biologist meets opportunities such as he has never, if ever, met before. Agriculture, biology and medicine are fields in which Inter-American co-operation has an opportunity to do things so great that no one can question their usefulness and need; moreover, they are things which have a very strong bearing upon Inter-American economic and political relations. Though many of us in the countries of the Western Hemisphere realize these simple facts and this dramatic opportunity thrown in our lap, not too many of us seem aroused, in spite of the support of the Government and our large foundations. Is it due to the intuitive reluctance of the man of science to get mixed up in Government projects ? Among biologists all over the world there is a feeling that relations with government (I do not mean any specific political group) should be avoided whenever possible. This may be a sound attitude from the point of view of pure research ; from all other points of view it is a mistake. It reveals poor ability to read the signs of the times. Who should know better than the biologist that with the development of organisms their ecology becomes more and more intricate ?

The structure of human society has become so complicated that it can no longer function well without regulation. This is not a political creed; it is a fact which we can observe all over the world. The government-to use a simple colloquialism -is there to stay, and we biologists should make of this opportunity what we can. Let us hope the biologist may see his opportunity and duty, for never before has he been in such a position to influence with simple means and little, if any, sacrifice the course of development of the Western Hemisphere directly and the world at large indirectly.

Much has been written during the past years about the form, aims and scope of inter-American cooperation in the pure and applied, plant and animal sciences. I will restrict myself to a few remarks and desiderata :

(1) Co-operative studies of the flora and fauna of tropical America are necessary, and more workers must be found for this work, even if it means some discontinuance of research of the Old World tropics.

(2) Students must be exchanged on a much larger scale.

(3) The problem of a common language must be solved in some way. Very probably it will find its solution best if the Latin American men of science make an increased use of English in their scientific publications and correspondence abroad. Their North American neighbour, however, must be able to read Spanish, both to understand the publications of his Hispanic colleagues and to appreciate their culture, which differs considerably more from the North American than, for example, the British or Scan. dinavian.

(4) An inter-American professional biological journal, with articles and notes in the three languages, if possible backed by an inter-American biological society, seems desperately needed to establish a common meeting ground.

(5) An inter-American biological station of the Woods Hole type, somewhere in Latin America, could do much good, especially if organized by biologists and agronomists, on a truly inter-American basis. It is very sad that the Inter-American Institute of Agriculture has not been organized by representative men of science. With the same means and effort something better could have resulted. But the biologists of the Americas are also at a fault for having watched (or not having watched at all) the development of this Institute with such an utter detachment.

I have devoted much space in my Chronica Bolanica for the past few years to the promotion of interAmerican relations and will shortly issue a volume entitled "Plants and Plant Science in Latin America". A single individual, however, cannot do very much. An inter-American biological society, an interAmerican biological journal, and an inter-American biological station are needed; the latter will assure us of more satisfaction than merely a pleasant scientific holiday.

The biologists of the United Nations are, or will soon find themselves, in a truly unique position.

Some of them will have the opportunity of assuming leadership in the conduct of international relations work, with its profound implications. 
A group of them can be instrumental in assisting in making the Western Hemisphere strong and influential, one of the least Utopian guarantees of a durable peace.

Further, they will all be in a position to assist with the creation not of a planned supreme State, which is the criterion of all values, but of a government of free responsible men, which will guide human relations and world affairs according to the laws of living Nature, as discovered and set forth by biologists.

\section{CONSTITUTIONAL ISSUES IN SOUTH-EAST AFRICA}

\author{
By PROF. DARYLL FORDE \\ International African Institute
}

$\mathrm{T}$ HE recent announcement by the Secretary of State for the Colonies concerning the establishment of a standing Central African Council for the three territories of Southern Rhodesia, Northern Rhodesia and Nyasaland represents a further step in the attempt to secure an orderly solution of economic problems and political issues that have been intensified by the War. These three contiguous territories, each with an African population of about one and a half millions, share in varying degrees the problems that arise from the introduction of Western technology and white settlement in Africa. The issues are, however, by no means identical in each territory, and these differences, together with a conflict between the British Government and local white sentiment over long-term native policy, present serious obstacles to satisfactory constitutional development.

Southern Rhodesia, with a European population of about 69,000, has had virtual Dominion status since 1923, and its executive government is responsible through the legislature to an electorate practically confined to whites. Although its constitution reserves to the Secretary of State for the Dominions considerable control over native affairs, this is of limited practical effect. The segregation of the native population and their exclusion from some occupations, in order to protect Europeans from native competition, are, as in South Africa, avowed objects of both the Government and the European population.

A substantial majority of the white population of about 13,000 in the Protectorate of Northern Rhodesia, most of them directly or indirectly dependent on the mining industries, share the sentiments of the white Southern Rhodesians. Despite the absence of any legal sanctions and the positive legislation of the Protectorate, they too are able, in practice, to impose restrictions on the employment and status of the native population.

In the Protectorate of Nyasaland, on the other hand, with a small white population of less than 2,000 planters, the principle of trusteeship and "the paramountcy of native interests" which is accepted by the British Government and so widely endorsed in Great Britain meets with less effective local opposition.

The whole problem is still further complicated by the fact that a very large proportion of the African male population, amounting to more than 100,000 in each of the territories, is employed as migrant labour on European farms and mines away from its native settlements. This has not only produced serious dislocation in native agriculture and community life, which is bitterly resented by champions of the African cause, but also, since there is a large-scale migration of labour across frontiers, calls for co-ordinated action in all the territories concerned.

The Southern Rhodesia Government has, over a number of years, pressed for the unification of the three territories under a responsible government which could, among other things, deal with the labour problems of the area as a whole. The evidence given to the Bledisloe Commission of 1938 revealed strong native opposition to amalgamation on which the Commission itself could not agree; but the impact of the War and the contribution of the white peoples of Africa to the defence of the Empire have sharpened the issue. The regional grouping of colonies in the interests of technical development and administrative e ticiency has gained increasing support, while General Smuts, in his speech at the end of last year, claimed for the Dominions a larger share of responsibility for the colonial territories in their respective spheres - in other words, the increasing influence of South Africa in the development of the southern African territories. The Prime Minister of Southern Rhodesia, Sir Godfrey Huggins, had earlier secured an undertaking that the question of amalgamation should not necessarily be postponed until after the War ; while to meet the urgent needs of production and supply during the War, the Governors' Conference of these three south-east African territories has been supplemented by a joint secretariat.

The British Government now proposes to set up a standing Central African Council with a permanent secretariat, to deal with matters of common interest to the three territories. While only consultative, it is designed to provide machinery for the permanent co-operation of the administrative and technical services of the three Governments in such fields as industry, agrieulture, labour, education and medical services. It is intended, in the words of the statement, that "leading unoificials in Southern Rhodesia and Nyasaland should be closely associated with the work of the Council", and it is recognized "that the Southern Rhodesia Government still adhere to their view that the three territories should be amalgamated". Amalgamation is, however, regarded as not being practicable "in existing circumstances", which, as Colonel Stanley explained in answer to questions in the House of Commons, refers not merely to the continuance of the War but also to "the difference in African policy between the territories".

At the same time it is proposed to take a further step forward in the constitutional development of the Northern Rhodesia Protectorate by increasing the uno.$_{L}$ cial membership of the Legislative Council from one to five, of whom three will represent the interests of the African community. The statement declares that "it is intended that African interests in the Legislative Council should be represented by Africans as soon as a suitable basis of representation can be built up", and the British Government is looking to the recently established Provincial African Councils as a political nursery for this development. This announcement concerning Northern Rhodesia, together with the express limitations on the powers of the Central African Council, makes it clear that the British Government still seeks to promote the growth of an educated and politically experienced African population which shall play its part in government. 